\title{
Mast cell leukemia
}

INSERM

\section{Source}

INSERM. (1999). Orphanet: an online rare disease and orphan drug data base. Mast cell leukemia. ORPHA:98851

Mast cell leukemia is a malignant form of systemic mastocytosis (SM; see this term) characterized, most of the time, by the presence of circulating mast cells. 